\title{
Terapia por Ondas de Choque nas Lesões Traumato Ortopédicas: Revisão Sistemática
}

\section{Shock wave therapy in traumatic orthopedic Injuries: Systematic Review}

Marcelo Baptista Dohnert ${ }^{1}$; Jéssica de Oliveira Sousa ${ }^{2}$; Thaíssa Araújo Vale dos Santos $^{2}$; Áktor Hugo Teixeira ${ }^{3}$

\section{RESUMO}

INTRODUÇÃO: A terapia por ondas de choques extracorpóreas é uma técnica não invasiva que trabalha com ondas de energia mecânica que penetram os tecidos lesados, liberando substâncias anti-inflamatórias locais e estimulando um aumento circulatório na área com a finalidade de causar regeneração dos tecidos. O objetivo do estudo foi realizar uma ampla revisão na literatura acerca dos efeitos fisiológicos da terapia por ondas de choque na reabilitação de lesões traumato-ortopédicas.

MÉTODOS: Revisão sistemática de literatura realizada nas bases de dados PubMed, Medline, Cochrane Library, Science Direct, Lilacs e SciELO. Considerou-se artigos publicados no período de 2015 a 2020. Foram inicialmente encontrados 51 artigos. Após a leitura de títulos, resumos e artigos completos, 42 artigos foram excluídos por não preencherem os critérios de inclusão. Portanto, a revisão contou com 10 estudos. CONCLUSÃO: Apesar do baixo número de estudos encontrados na literatura e de suas diferenças metodológicas, podemos concluir que não existem evidências de resultados superiores para a terapia por ondas de choque em comparação às outras terapias utilizadas na abordagem de lesões musculoesqueléticas.

Palavras-chave: Modalidades de Fisioterapia, Eletroterapia, Ferimentos e Lesões.

\section{ABSTRACT}

INTRODUCTION: Extracorporeal shock wave therapy is a noninvasive technique that uses mechanical waves that penetrate injured tissues. The procedure releases local anti-inflammatory substances and increases local blood circulation, leading to tissue regeneration. This study is a comprehensive literature review on the physiological effects of shock wave therapy on the rehabilitation of traumatic orthopedic injuries.

METHODS: Systematic literature review conducted in the PubMed, Medline, Cochrane Library, Science Direct, Lilacs, and SciELO databases. We analyzed articles published from 2015 to 2020 . We initially found 51 articles. After reading the titles, abstracts, and full articles, we excluded 42 articles for not meeting the inclusion criteria. Therefore, the review included 10 studies.

CONCLUSION: Despite the low number of studies and their methodological differences, we conclude that there is no evidence of better results for shock wave therapy compared to other therapies used to approach musculoskeletal injuries.

Keywords: Physical Therapy Modalities, Electric Stimulation Therapy, Wounds and Injuries
Physiotherapist. Professor. Doctor. University of Gurupi (UnirG). Gurupi-TO, Brazil. Email:mdohnert@unirg.edu.br

${ }^{2}$ Academics of the University of Gurupi (UnirG). Gurupi-TO, Brazil. E-mail:

thadireito@hotmail.com

Physiotherapist. Professor. University of Gurupi (UnirG). Gurupi-TO, Brazil. E-mail: aktorhugoteixeira@hotmail.com 


\section{INTRODUÇAOO}

Extracorporeal shock wave therapy (ESWT) is a noninvasive technique derived from urological lithotripsy. Initially, it consisted of generating sound waves with amplitude and frequency controlled from an external source of energy. These waves were directed by a collimator (device used to direct and smooth radiation beams or waves) and placed on renal stones, thus imploding or crushing them. ${ }^{1}$ The technique became part of medical practice in the early 90 s for destroying solid deposits (stones) in organs such as kidneys and gallbladder. ${ }^{1}$ In the past fifteen years, this technology has also been used to treat various musculoskeletal conditions such as shoulder calcifying tendinitis, plantar fasciitis, lateral epicondylitis, fractures, among others. ${ }^{1}$

The shock wave (or impact wave) is a sonic pulse or mechanical energy derived from a specific generator. It is transferred to the transmitter at the end of the applicator and thus transported into the tissue. ${ }^{2}$ This energy is characterized by large positive pressure variation and high amplitude. ${ }^{2}$ Its transmittance depends on the physical properties of the tissue to which it is applied (liquid or solid). ${ }^{2}$ Shock waves act mechanically, causing a phenomenon known as cavitation. This phenomenon translates into the formation of microbubbles that break up, fragmenting local fibrosis and providing an analgesic effect with the release of local enzymes that act in pain physiology. Moreover, it leads to vascular congestion and neoformation. ${ }^{2}$

Shock waves cause a direct effect and an indirect effect. The direct effect consists of the impact from the mechanical waves into transmission of the tissues. ${ }^{3}$ In turn, the indirect (secondary) effect corresponds to cavitation, that is, formation of gaseous microbubbles in biological liquids. ${ }^{3}$ Cavitation can be stable or unstable. ${ }^{3}$ Stable cavitation occurs when bubbles oscillate from side to side within pressure waves, increase and decrease in size, but remain intact. ${ }^{3}$ This effect is considered normal and desirable, as it provides a therapeutic effect. ${ }^{3}$ Unstable cavitation comprises a violent implosion of these bubbles, and occurs at high peak intensities. ${ }^{4}$ The high temperatures and pressures generated by energy release in this phenomenon can damage tissues. ${ }^{4}$ Moreover, the high intensity ends up breaking molecular bonds, thus producing free radicals, hydrogen and hydroxyl ions, and reactive oxygen species (ROS). ${ }^{4}$

Extracorporeal shock wave therapy (ESWT) initially generates a series of physiological anti-inflammatory effects (direct effects) in the injured tissue. These include increased microcirculation and angiogenesis, supply of nitric oxide (NO) and substance P 
at the inflammation site, as well as inhibition of the COX-II enzyme. ${ }^{5}$ Indirect effects, on the other hand, correspond to: activating collagen production in tissues; stimulating blood circulation, the lymphatic system, and fibroblasts; stimulating protein and elastin synthesis; and inducing lipolysis in adipocytes, where microbubbles break, causing microruptures in the inflamed tissue. This latter event determines the release of local anti-inflammatory substances and stimulates local microcirculation. ${ }^{5}$

As with therapeutic ultrasound, the acoustic waves used in ESWT are mechanical waves propagated from a generating source and absorbed by the organism (inverse piezoelectric effect). ${ }^{6}$ It differs from ultrasound in that it generates a high energy peak, leading to accelerated tissue repair and cell growth, analgesia, and restoration of mobility. ${ }^{6}$ It is indicated as a therapeutic resource in acute, subacute, and chronic conditions, being therapeutically separated by frequency bands. ${ }^{6}$ The penetration depth depends on the transmitter and the defined energy. ${ }^{6}$ Penetration values range from 4 to $7 \mathrm{~cm}^{6}{ }^{6} \mathrm{~A}$ substantial part of the energy enters the body by positive pressure pulses, thus allowing increased metabolism and microcirculation, dissolution of calcified fibroblasts, acceleration of collagen production, reduction of muscle tension, and cleansing of substance $\mathrm{P}$ in cells. ${ }^{6}$

This study consists of a comprehensive review of the effects of shock wave therapy on the rehabilitation of traumatic orthopedic injuries. Our hypothesis is that ESWT has significant physiological effects on the therapeutic approach to musculoskeletal injuries.

\section{MATERIAIS E METODOS}

The present study is a systematic literature review. We searched for articles in the following electronic databases: PubMed, Medline, Cochrane Library, Science Direct, Lilacs, and SciELO. For that purpose, we used the following keywords: extracorporeal shock wave therapy and musculoskeletal injury.

We restricted the search to articles on human studies, including clinical trials in Portuguese and English published in the last five years. For the selection of articles, we used the following inclusion criteria: (I) design (randomized clinical trials); (II) population (subjects with musculoskeletal injury); (III) intervention (extracorporeal shock wave therapy - ESWT); (IV) result (improvement or not of pain, mobility, strength, and function). We excluded studies that did not meet the inclusion criteria and animal studies. We initially preselected all articles by reading the titles. Afterwards, we read and analyzed the abstracts. Only articles from the last five years of publication were included in the search. 
DOI: 10.18606/2318-1419/amazonia.sci.health.v8n2p31-41 Revista Amazônia Science \& Health 2020, Vol. 8, № 2
DOHNERT, MB. SANTOS, JOS. TEIXEIRA, AH

Terapia por Ondas de Choque nas Lesões Traumato

Ortopédicas: Revisão Sistemática

\section{RESULTADOS}

From the terms used for the search, 51 articles were initially found. After reading the abstracts, 42 articles were excluded because they did not meet the inclusion criteria. Therefore, the review included nine studies (Figure 1).

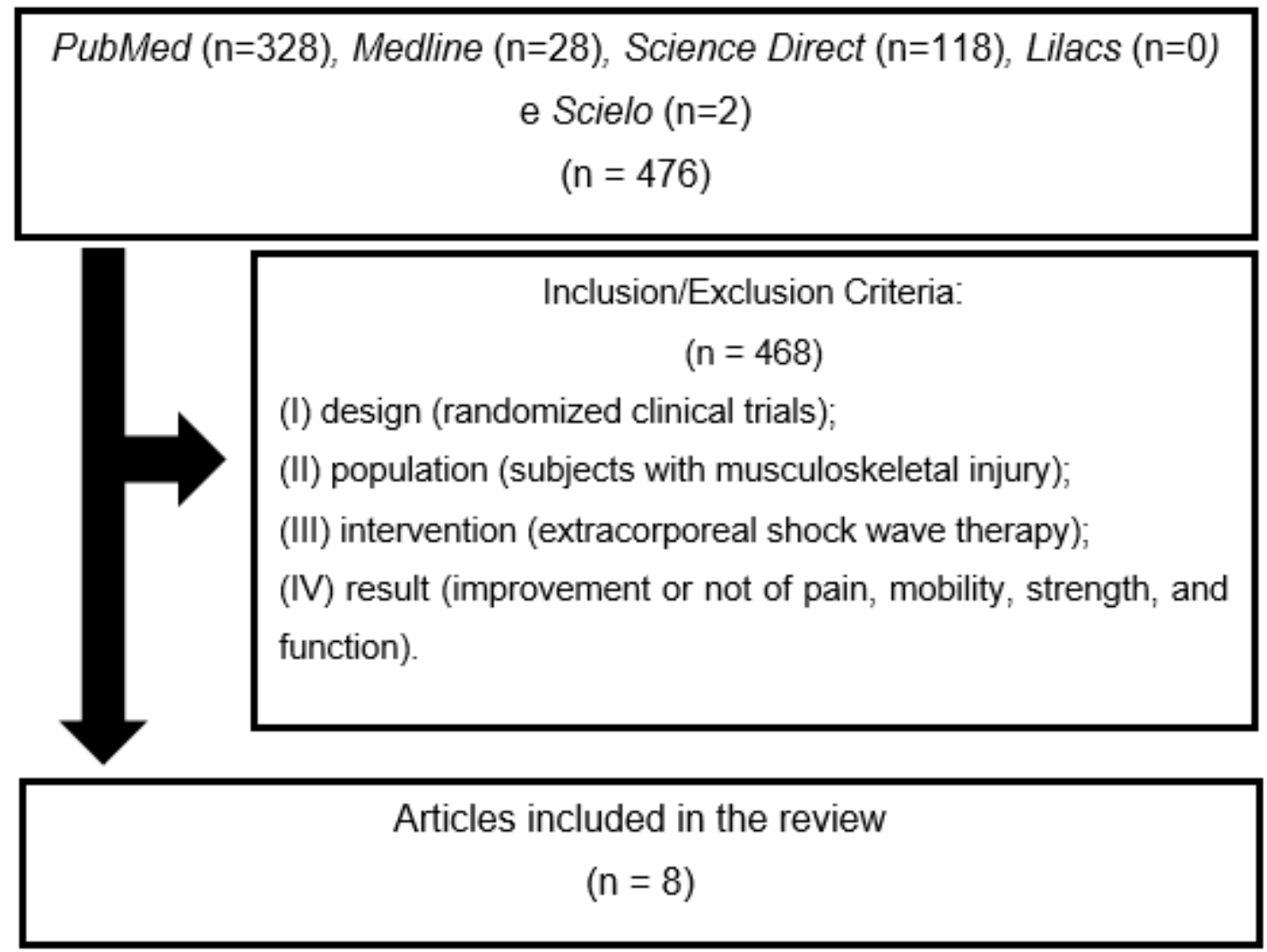

Table 1 shows the selected studies in chronological order, highlighting their main characteristics such as used sample, intervention, study characteristics, and results.

Table 1. Characterization of the studies included in the review.

\begin{tabular}{|c|c|c|c|c|c|}
\hline AUTHOR & SAMPLE & INTERVENTION & $\begin{array}{l}\text { EVALUATED } \\
\text { OUTCOME }\end{array}$ & ESWT PARAMETERS & $\begin{array}{c}\text { RESULTS AND } \\
\text { CONCLUSION }\end{array}$ \\
\hline $\begin{array}{l}\text { Wong CW et } \\
.2016^{8}\end{array}$ & $\begin{array}{l}\text { - } 34 \text { patients with } \\
\text { lateral elbow } \\
\text { epicondylitis }\end{array}$ & $\begin{array}{l}\text { - ESWT Group } \\
\text { (ESWTG) }(n=17) \\
\text { - Acupuncture } \\
\text { Therapy Group (ATG) } \\
(n=17)\end{array}$ & $\begin{array}{l}\text { - VAS; } \\
\text { - Grip strength } \\
\text { (dynamometer); } \\
\text { - DASH } \\
\text { Questionnaire }\end{array}$ & $\begin{array}{l}\text { - Frequency: } 2000 \mathrm{~Hz} \text {; } \\
\text { - Energy density: between } \\
0.032 \text { and } 0.822 \mathrm{~mJ} / \mathrm{mm}^{2} \text {. }\end{array}$ & $\begin{array}{l}\text { - Both groups decreased } \\
\text { VAS pain scores; } \\
\text { - The groups did not } \\
\text { differ significantly. }\end{array}$ \\
\hline $\begin{array}{l}\text { Weckström K et } \\
., 2016^{9}\end{array}$ & $\begin{array}{l}\text { - } 24 \text { runners with } \\
\text { iliotibial band } \\
\text { syndrome }\end{array}$ & $\begin{array}{l}\text { - Extracorporeal } \\
\text { shock wave therapy } \\
\text { group (ESWTG) } \\
\text { (n=11) } \\
\text { - Manual therapy } \\
\text { group (MTG) }(n=13)\end{array}$ & $\begin{array}{l}\text { - Pain while running } \\
\text { on a treadmill (VAS) }\end{array}$ & $\begin{array}{l}\text { Initial session: } \\
\text { Three points on the side of } \\
\text { the thigh; } \\
500 \text { pulses; } \\
\text { Intensity: } 0.10 \mathrm{~mJ} / \mathrm{mm}^{2} \text {; } \\
\text { Pressure: } 2 \mathrm{bar} ; \\
\text { Frequency: } 15 \mathrm{~Hz} \text {. }\end{array}$ & $\begin{array}{l}\text { - Both groups decreased } \\
\text { pain, not differing } \\
\text { significantly from each } \\
\text { other. }\end{array}$ \\
\hline
\end{tabular}


DOI: 10.18606/2318-1419/amazonia.sci.health.v8n2p31-41 Revista Amazônia Science \& Health 2020, Vol. 8, № 2
DOHNERT, MB. SANTOS, JOS. TEIXEIRA, AH

Terapia por Ondas de Choque nas Lesões Traumato

Ortopédicas: Revisão Sistemática
- Newman P Adams R,

Waddington $\mathrm{G}$ $2016^{10}$

- Frizziero A et
al., $2017^{11}$

et al., $2017^{12}$

Raissi GR et al., $2017^{13}$

- 28 athletes with
medial tibial stress
syndrome
syndrome

- 34 patients with rotator cuff tendinopathy

- 45 patients with Delayed-Onset Muscle Soreness (DOMS)

- 40 participants with carpal tunnel syndrome

- Last session:

Three points on the side of the thigh;

700 pulses;

Intensity: $0.10-0.4 \mathrm{~mJ} / \mathrm{mm}^{2}$;

Pressure: 2 - 4 bar;

Frequency: $15 \mathrm{~Hz}$.

- $\quad$ ESWT + Wrist Splint Group $(\mathrm{n}=20)$;

- Wrist Splint Group $(n=20)$

$\begin{array}{ll}\text { - Experimental ESWT } & \bullet \text { NRS } \\ \text { Group }(E G)(n=14) & \bullet \text { Pain while running } \\ \text { - Placebo ESWT } & \text { : GROC } \\ \text { Group (PG) }(n=14) & \text { Questionnaire }\end{array}$

- LMW-HA Injections

Group $(n=17)$

- ESWT Group

$(\mathrm{n}=17)$

DASH

Questionnaire

- Constant Score
- Week 1: 1,000 pulses; Intensity: $0.1-0.3 \mathrm{~mJ} / \mathrm{mm}^{2}$.

- Week 2: 1,500 pulses; $0.15 \mathrm{~mJ} / \mathrm{mm}^{2}$;

- Week 3: $0.2 \mathrm{~mJ} / \mathrm{mm}^{2}$

- Week 5: 1,500 pulses; $0.25 \mathrm{~mJ} / \mathrm{mm}^{2}$;

- Week 9:

1,500 pulses;

$0.3 \mathrm{~mJ} / \mathrm{mm}^{2}$;

- Total accumulated dose:

$1450 \mathrm{~mJ} / \mathrm{mm}^{2}$.

- 4 weekly sessions;

- 1,600 pulses;

- Frequency: $4 \mathrm{~Hz}$;

- Intensity: $0.15 \mathrm{~mJ} / \mathrm{mm}^{2}$.

- Energy intensity: 0.06 -

- VAS

- Threshold

- MVIC

Place
$(\mathrm{n}=15)$

- Control Group

$(n=15)$

$.09 \mathrm{~mJ} / \mathrm{cm}^{2}$ per point

- Pulse rate: 200 per point;

- 7 equidistant points on the biceps brachii;

- 1,400 pulses;

- Total energy: 10.3 - 15.4

$\mathrm{mJ} / \mathrm{cm}^{2}$.

- Three weekly sessions;

- Pressure: 1.5 bar;

- 6 pulses per second.

- VAS

- Electroneuromyogra phy
- The groups did not differ neither for NRS nor for pain while running.

- $\quad$ Both groups improved the Constant Score and the DASH score, not differing from each other.

- $\quad$ No short-term effects of ESWT. Apparent improvement in muscle pain after $48-72$ hours.

- Improvement of the Quick DASH score after 3 weeks in the ESWT group and after 8 weeks in the

Wrist Splint group

- $\quad$ Both groups improved pain after 3 weeks;

- $\quad$ Both groups improved median nerve sensory conduction and distal motor latency.

- 50 patients with lateral elbow epicondylitis

- 176 patients with moderate to severe knee osteoarthritis

\author{
- Group 01 - US \\ Group ( $\mathrm{n}=24)$ \\ - Grupo 02 - ESWT \\ Group ( $\mathrm{n}=20)$ \\ - ESWT Group \\ (ESWTG) $(n=82)$ \\ - Anti-inflammatory \\ Group (AG) ( $n=104)$
}

- VAS

- Pressure algometer

- Grip strength

- QDASH

- PRTEE

- SF-36

- VAS;

- Western Ontario and McMaster Arthritis Index (WOMAC)

- Cartilage injury

score

- 50-m gait test
- Three weekly sessions;

- Frequency: $10-15 \mathrm{~Hz}$;

- Pressure 1.5 - 2.5 bar;

- 2,000 pulses.

- Frequency: $8 \mathrm{~Hz}$;

- Intensity: $0.25 \mathrm{~mJ} / \mathrm{mm}^{2}$;

- Two sessions per week for four weeks.
- All outcome variables improved in both groups, with no differences between groups.

- The anti-inflammatory group (AG) significantly decreased pain and WOMAC scores at 12 and 16 weeks compared to the extracorporeal shock wave therapy group (ESWTG). 
Extracorporeal shock wave therapy (ESWT) is part of the therapeutic approach to several musculoskeletal conditions. ${ }^{7}$ Recent reports show its positive effects on chronic pain. ${ }^{16}$ It is a noninvasive technique that transmits sonic pulses with therapeutic properties through an appropriate generator. ${ }^{17}$ One of its main therapeutic actions is to produce a controlled microrupture in the tissue to which it is applied. This microrupture leads to neovascularization, therefore assisting in the repair of the injured musculoskeletal tissue. ${ }^{18}$ The therapeutic action is determined by the penetration of waves in the tissues, vessels, and nerves. ${ }^{1}$ Upon reaching the injured site, shock waves mechanically induce a series of biological effects, including: increased production of prostaglandins related to tissue repair; increased local blood microcirculation; and increased concentration of local nitric oxide with pain relief. ${ }^{1}$ However, the results obtained with this technique in musculoskeletal injuries continue to be quite dismal from the point of view of the scientific evidence demonstrated.

Zhong et al. conducted a randomized controlled study to assess the effects of lowdose ESWT in patients with knee osteoarthritis. ${ }^{17}$ The authors selected sixty-three (63) patients with symptoms of knee osteoarthritis. ${ }^{17}$ Thirty-two (32) patients received ESWT and thirty-one (31) received placebo treatment. ${ }^{17}$ All patients were evaluated by an independent evaluator at the beginning of the study, at five weeks, and 12 weeks after the intervention. ${ }^{17}$ The results of the study showed no differences between the two groups regarding pain (VAS), WOMAC score, and Lequesne index. ${ }^{17}$

Another study investigated the cumulative effect of combining medium-energy ESWT and photobiomodulation therapy (PBMT) in the management of plantar fasciitis (PF). ${ }^{18}$ The authors studied one-hundred and twenty (120) patients, 56 men and 64 women, with ages ranging from 40 to 70, divided into PBMT + ESWT group, ESWT group, PBMT group, and control group. ${ }^{18}$ Both ESWT and PBMT were effective in decreasing pain and increasing function. ${ }^{18}$ Moreover, the combination of PBMT and ESWT proved to be superior to the isolated treatments in terms of reducing pain sensitivity and increasing function. ${ }^{18}$ prospective randomized controlled trial analyzed 86 patients with rotator cuff tendinopathy, randomly divided to receive either ESWT, electromagnetic transduction therapy (sham-EMTT), or their combination. ${ }^{19}$ The study found that both groups improved the scores compared to the initial assessment. However, ESWT in isolation has not shown the significant effects observed for its combination with EMTT. ${ }^{19}$

Cheng et al. studied 51 athletes who attended the Rehabilitation Center of the Sichuan Institute of Sports Skills from January 2015 to October $2017 .{ }^{20}$ The authors 
assessed knee joint isokinetic strength in athletes with patellar tendinopathy, excluding subjects who had knee joint injury, muscle injury, or history of knee surgery. ${ }^{20}$ Participants were allocated to an experimental group $(n=26)$ and a control group $(n=25){ }^{20}$ Individuals in the experimental group received 16 cycles of ESWT once a week, with a total of 2,000 shocks per session, strength of 1.5 to $3.0 \mathrm{bar}$, and frequency of 9 to $12 \mathrm{~Hz} .^{20}$ The control group received acupuncture at the site of pain, ultrasound, and microwave therapy. ${ }^{20}$ Sites of treatment were the lower patella and the base of the patellar tendon. ${ }^{20}$ The group that received ESWT had a positive effect on patellar tendinopathy, relieving pain and improving knee strength compared to other treatments. ${ }^{20}$

Park et al. compared high energy and low energy extracorporeal shock wave therapy (ESWT) in the therapeutic approach of patients with upper trapezius myofascial pain syndrome, divided into high energy $(n=15)$ and low energy groups $(n=16) .{ }^{21}$ The authors concluded that high energy shock waves are superior for pain reduction and functional improvement compared to low energy ones. ${ }^{21}$

Celik and Kulunkoglu studied 52 patients diagnosed with lateral epicondylitis. Of these, 26 were allocated to the photobiomodulation (PBMT) group and 26 to the ESWT group. ${ }^{22}$ Both groups performed eccentric exercises for the wrist extensor muscles. ${ }^{22}$ The authors concluded that the patients improved short-term handgrip strength after application of ESWT. ${ }^{22}$ There were no other significant differences between treatment groups. ${ }^{22}$ Both therapeutic options can be used in the treatment of lateral epicondylitis. ${ }^{22}$ However, PBMT can be considered a more economical procedure than ESWT. ${ }^{22}$

Manafnezhad et al. compared the effects of ESWT with dry needling (DN) techniques on active trigger points of upper trapezius muscle in patients with nonspecific neck pain. ${ }^{23}$ The study included 70 patients, 49 women and 21 men, with mean age of 38 years. ${ }^{23}$ Treatment was performed once a week for three weeks. ${ }^{23}$ Functional results were significantly better in both groups. ${ }^{23}$ However, the groups did not differ significantly for pain intensity, neck disability index (NDI), and pain pressure threshold (PPT). ${ }^{23}$ In conclusion, both therapies can be administered to treat chronic pain in the upper trapezius muscle and at trigger points in the same region. ${ }^{23}$

Lai et al. studied 97 patients with chronic plantar fasciitis to compare the results obtained with ESWT and corticosteroid injections $(\mathrm{Cls}){ }^{24}$ The results showed increased plantar fascia thickness in the ESWT compared to the $\mathrm{Cl}$ group after four weeks. ${ }^{24}$ Patients in the ESWT group decreased pain compared to those who received a single injection of corticosteroids. ${ }^{24}$ On the other hand, the increase in plantar fascia thickness in 
the fourth week was positively correlated with the decrease in pain. In conclusion, ESWT was more efficient than corticosteroid injections (Cls) in treating chronic plantar fasciitis. ${ }^{24}$

Walewickz et al. evaluated the influence of ESWT in patients with low back pain (LBP). ${ }^{25} \mathrm{~A}$ total of 40 patients with LBP were randomly divided into two comparative groups. ${ }^{25}$ Group A $(\mathrm{n}=20)$ corresponded to ESWT (2,000 pulses; 2.5 bar; $5 \mathrm{~Hz} ; 7$ minutes) performed twice a week for five weeks (10 sessions), in addition to stabilization training; group B $(n=20)$ corresponded to placebo ESWT and stabilization training. ${ }^{25}$ The study also included patients with L5-S1 discopathy with pain longer than three months. ${ }^{25}$ The authors concluded that ESWT was efficient for patients with LBP, both in the short and long term. ${ }^{25}$ This therapy significantly decreased pain and improved general function compared to a conventional motor improvement program. ${ }^{25}$

\section{CONCLUSOES}

Evidence found in the literature does not allow us to reach a definitive conclusion about the effects of ESWT on musculoskeletal injuries due to the low quality and large methodological variation of studies. However, the current results presented do not allow us to conclude that ESWT has better physiological effects than other therapies proposed for this type of injury. In addition, the little literature found on the subject and the wide variation of ESWT parameters used in musculoskeletal conditions do not make clear the therapeutic indication of this resource. New clinical studies with strict methodological care must be carried out for the therapeutic confirmation of ESWT.

\section{REFERÉNCIAS}

1. Kertzman P, Lenza M, Pedrinelli A, Ejnismand B. Ondas de choque nas doenças musculoesqueléticas e consolidação óssea: Análise qualitativa da literatura. Rev Bras Ortop. $2015 ;$ 50(1): 3-8.

2. Pai MYB, Toma JT, Rampim DB, Imamura M, Battistella LR. Benefício da terapia de ondas de choque no tratamento de úlceras cutâneas: uma revisão da literatura. Acta Fisiatr. 2016; 23(1): 35-41.

3. Borges FS. Dermato funcional: modalidades nas disfunções estéticas. 2.ed. São Paulo: Phorfe, 2006.

4. Guirro E, Guirro R. Fisioterapia dermato funcional: fundamentos, recursos e patologias.

3. ed. São Paulo: Manole, 2004. 
5. Hammer DS, Rupp S, Kreutz A, Pape D, Kohn D, Seil R. Extracorporeal shockwave therapy (ESWT) in patients with chronic proximal plantar fasciitis. Foot Ankle Int. 2002; 23(4):309-13.

6. Dymarek R, Halsk T, Ptaszkowski K, Slupska L, Rosinczuk J, Taradaj J. Extracorporeal Shock Wave Therapy as an adjunct wound treatment: a systematic review of the literature. Ostomy Wound Manage. 2014; 60(7):26-39.

7. Lynen N, De Vroey T, Spiegel I, Van Ongeval F, Hendrickx N-J, Stassijns G. Comparison of peritendinous hyaluronan injections versus extracorporeal shock wave therapy in the treatment of painful Achilles tendinopathy: A randomized clinical efficacy and safety study. Arch Phys Med Rehabil. 2017; 98(1): 64-71.

8. Wong CW, Ng EY, Fung P, Mok K, Yung PS, Chan K. Comparison of treatment effects on lateral epicondylitis between acupuncture and extracorporeal shockwave therapy. Sports Med Arthrosc Rehabil Ther Technol. 2017; (7): 21-26.

9. Weckström K, Söderström J. Radial extracorporeal shockwave therapy compared with manual therapy in runners with iliotibialband syndrome. J Back Musculoskelet. 2016, 29(1):161-70.

10. Newman P, Waddington G, Adams R. Shockwave treatment for medial tibial stress syndrome: a randomized double blind sham-controlled pilot trial. J Sport Sci Med. 2017, 20(3):220-224.

11. Frizziero A, vittadini F, Barazzuol M, Gasparre G, Finotti P, Meneghini A, et. Al. extracorporeal shockwaves therapy versus hyaluronic acid injection for the treatment of painful non-calcific rotator cuff tendinopathies: preliminary results. J Sport Med Phys Fit. 2017; 57(9):1162-1168.

12. Fleckenstein J, Friton $\mathrm{M}$, Himmelreich $\mathrm{H}$, Banzer W. Effect of a single administration of focused extracorporeal shock wave in the relief of Delayed-Onset Muscle Soreness: results of a partially-blinded randomized controlled trial. Arch Phys Med Rehabil. 2017; 98(5):923-930.

13.Raissi G R, Ghazaei F, Forogh B, Madani S P, Daghaghzadeh A, Ahadi T. The effectiveness of radial extracorporeal shock waves for treatment of carpal tunnel syndrome: a randomized clinical trial. Ultrasound Med Biol. 2017; 43(2):453-460.

14.Yalvaç B, Mesci N, Külcü DG, Yurdakul OV. Comparison of ultrasound and extracorporeal shock wave therapy in lateral epicondylosis. Acta Orthop Traumatol Turc. 2018; 52(5):357-362.

15.Xu Y, Wu K, Liu Y, Geng H, Zhang H, Liu S, et.al. The effect of extracorporeal shock wave therapy on the treatment of moderate to severe knee osteoarthritis and cartilage lesion. Med. 2019; 98(20):155-23.

16.Klüter T, Krath A, Stukenberg M, Gollwitzer H, Harrasser N, Knobloch K, et al. Electromagnetic transduction therapy and shockwave therapy in 86 patients with rotator 
cuff tendinopathy: A prospective randomized controlled trial. Electromagn Biol Med. 2018; 37(4):175-183.

17.Zhong Z, Liu B, Liu G, Chen J, Li Y, Chen J, et al. A Randomized Controlled Trial on the Effects of Low-Dose Extracorporeal Shockwave Therapy in Patients wth Knee Osteoarthritis. Am J Phys Med Rehabil. 2019; 100(9):1695-1702.

18.Takla MKN, Allah Rezk SSR. Clinical effectiveness of multi-wavelength photobiomodulation therapy as an adjunct to extracorporeal shock wave therapy in the management of plantar fasciitis: a randomized controlled trial. Laser Med Sci. 2019; 34(3):583-593.

19.Klüter T, Krath A, Stukenberg M, Gollwitzer H, Harrasser N, Knobloch K, et al. Electromagnetic transduction therapy and shockwave therapy in 86 patients with rotator cuff tendinopathy: A prospective randomized controlled trial. Electromagn Biol Med. 2018; 37(4):175-183.

20.Cheng L, Chang S, Qian L, Wang Y, Yang M. Extracorporeal shock wave therapy for isokinetic muscle strength around the knee joint in athletes with patellar tendinopathy. $J$ Sport Med Phys Fit. 2019; 59(5):822-827.

21.Park KD, Lee WY, Park M, Ahn JK, Park Y. High- versus low-energy extracorporeal shockwave therapy for myofascial pain syndrome of upper trapezius:A prospective randomized single blinded pilot study. Med. 2018; 97(28):e11432.

22. Celik D, Kulunkoglu BA. Photobiomodulation Therapy versus Extracorporeal Shock Wave Therapy in the Treatment of Lateral Epicondylitis. Photobiomodul Photomed Laser Surg. 2019; 37(5):269-275.

23. Manafnezhad J, Salahzadeh Z, Salami M, Ghader F, Ghojazadehb M. The effects of shock wave and dry needling on active trigger points of upper trapezius muscle in patients with non-specific neck pain: A randomized clinical trial. J Back Musculoskelet. 2019; 32(5):811-818.

24. Lai T, Ma H, Lee M, Chen $\mathrm{P}, \mathrm{Ku} \mathrm{M}$. Ultrasonography and clinical outcome comparison of extracorporeal shock wave therapy and corticosteroid injections for chronic plantar fasciitis: A randomized controlled trial. J Musculoskelet Neuronal Interact 2018; 18(1):4754.

25.Walewicz K, Taradaj J, Rajfur K, Ptaszkowski K, Kuszewsk M T, Sopel M, et al. The Effectiveness of Radial Extracorporeal Shock Wave Therapy In Patients With Chronic Low Back Pain: A Prospective, Randomized, Single-Blinded Pilot Study. Clin Interv Aging. 2019; 14: 1859-1869. 